\title{
Miranda
}

Revue pluridisciplinaire du monde anglophone /

Multidisciplinary peer-reviewed journal on the English-

speaking world

$4 \mid 2011$

Samuel Beckett : Drama as philosophical endgame?

\section{Fay Bound Alberti, Matters of the Heart: History, Medicine and Emotion}

Laurence Talairach-Vielmas

OpenEdition

Journals

Electronic version

URL: http://journals.openedition.org/miranda/5075

DOI: 10.4000/miranda.5075

ISSN: 2108-6559

Publisher

Université Toulouse - Jean Jaurès

Electronic reference

Laurence Talairach-Vielmas, "Fay Bound Alberti, Matters of the Heart: History, Medicine and Emotion", Miranda [Online], 4 | 2011, Online since 24 June 2011, connection on 16 February 2021. URL: http:// journals.openedition.org/miranda/5075 ; DOI: https://doi.org/10.4000/miranda.5075

This text was automatically generated on 16 February 2021.

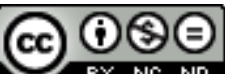

Miranda is licensed under a Creative Commons Attribution-NonCommercial-NoDerivatives 4.0 International License. 


\title{
Fay Bound Alberti, Matters of the Heart: History, Medicine and Emotion
}

\author{
Laurence Talairach-Vielmas
}

\section{REFERENCES}

Fay Bound Alberti, Matters of the Heart: History, Medicine and Emotion (Oxford: Oxford University Press, 2010), 307 p, ISBN 978-0-954097-6

1 Where is the seat of emotions and has it changed through time? This is one of the questions that Fay Bound Alberti's Matters of the Heart: History, Medicine and Emotion addresses, in a study that traces the trajectory of the meanings of the heart from the symbol of emotions to an organ subject to pathologies, medical theorizing and specialization. Still, as the book makes explicit, it is the enduring presence of the heart as an emotional organ which explains that the heart remains a problematic figure today, even if, or despite the fact that, neuro-physiology has placed the mind at the heart of emotions. Alberti's book explores the medical and cultural history of the heart from the classical world to the 20th century, analysing the shifting meanings of the heart, from its construction as a pump by scientific discourse to its links with the rhetoric of emotion that still survives in popular culture. As Alberti argues, if emotions have been studied by the mind sciences, the social sciences or the humanities, very little research has been carried out on the relationship between the heart and emotions during the eighteenth and nineteenth centuries. Her study thus offers a contextualization of the heart, the evolution of its definition and pathologies within the history of medicine, and above all proposes a cultural history of the heart, through famous case studies and examination of physician's papers.

2 The heart has long been seen as an organ of emotion. The image of the heart as a symbol of affect originates from classical ideas about the body and the mind, the Galenic medical tradition having permeated Western conceptions of the body for thousands of years. In her introduction, Alberti recalls how Galenic principles informed 
stereotypical constructions of the heart (such as "cold hearted" or "cold blooded" people) before the heart came to be conceived as a pump. With the rise of mechanical physiology and after William Harvey's theorizing on blood circulation, the body was understood as a series of pumps of all sorts. Yet, as science redefined the heart, its cultural meaning as an emblem of emotions was paradoxically enhanced. This is why combining a medical and cultural understanding of emotions is a good means to probe the traffic between science and its culture. Thus, Alberti focuses more particularly on the changing meanings of the emotional heart between the seventeenth and the nineteenth centuries, her study charting the "interconnectedness of heart, mind, body and soul", revealing "the gender- and class- based analyses at core in the construction of the cardiac patient" (13).

3 In Chapter 1, Alberti explains the status of the heart as an emotional symbol between the classical period and the 19th century. She situates the heart within the context of humoral theories, explaining how the rise of mechanistic physiology in the 17th century (marked by William Harvey's discovery of blood circulation in 1628) impacted constructions of emotions. As emotions were redefined by physiologists "as a product of sensory perception and material processes" (29), physiological research paved the way for the shift from cardio-centric to neuro-centric understandings of emotional experiences which the book traces.

Chapter 2 records a case study to highlight the emotional meanings of the heart within an 18th-century materialistic context: John Hunter's Angina Pectoris. Linked with emotional excesses, angina attacks were believed to result from rapid circulation of blood around the body which could harm the functioning of the heart by provoking strain on the organ. Hunter's Angina Pectoris was directly related to a particular event in Hunter's professional life: his fatal attack took place after a board meeting during which Hunter exhibited anger. The example shows that if Angina Pectoris seemed defined as an emotional disease, stressing to some extent the role of the heart in the connection between mind and body, it nevertheless pointed to Angina Pectoris as a structural disease that secularized the heart and its workings. Because the anatomist's temper was seen as the cause of his heart disease, the mechanistic vision of Angina Pectoris typified how emotions could disrupt the physical body, hence illustrating 18thcentury physiology: blood flow and blood pressure replaced humours, the discourse on hydraulics proposing a new version of the mind-body relationship. This evolving construction of the heart as partaking of a whole discourse on hydraulics went hand in hand with the rise of heart disease as a clinical specialism and of techniques of measurement and standardisation in the 19th century, as Chapter 3 explains. The emergence of new diagnostic techniques, such as mediate auscultation, the first diagnostic tool which enabled physicians to measure and assess heart sounds detected through stethoscopes (or later sphygmographs, sphygmomanometers, electrocardiographs and x-rays) evidences the change in diagnoses and classifications of heart diseases-"the technologizing of the heart beat" (85). Medical specialism in the first half of the 19th century typified the ways in which the functions of the heart were then seen as measurable and quantifiable, pointing to emotions as the cause of structural changes in the heart, from lesions to arterial obstruction. Such views of heart diseases were directly related to the rise of anatomical dissection and the development of pathological anatomy which participated in the scientific framing of the heart. Revealingly, unlike their colleagues on the Continent, British medical 
practitioners remained reluctant to use such technological innovations "in the bedside context" (86).

This idea is developed in the following chapter which draws upon Peter Mere Latham's autopsy of Thomas Arnold. Indeed, in his Lectures on Subjects Connected with Clinical Medicine, Comprising Diseases of the Heart (1845), Latham not only provides a good example of how the influence of emotion on the heart prevailed as a medical belief, but his therapeutic strategies also reveal that the physician did not pay much attention to the measurement and objectification of cardiac symptoms. The analysis of Latham's work in Chapters 4 and 5 furthers the exploration of the centrality of emotions in understandings of the heart and its diseases in 19th-century discourse. As Chapter 4 highlights, the treatment of Thomas Arnold's cardiac pathology was directly related to the rise of heart diseases in the second half of the 19th century and the connections that were made between cardiac pathologies and the stresses of modern life. Diseases of the heart were increasingly believed to result from emotional strain. Chapter 5 elaborates further on the work of Latham through his own casebooks which provide good examples of how patients' symptoms and complaints were recorded by physicians. Alberti looks at the way in which physicians emphasized the significance of the pulse, noting the type of treatment Latham prescribed, from bloodletting and purging to vomiting.

Chapter 6 moves away from the accounts in the early chapters of the increased materialization of the heart from the classical period to the 19th century and offers a counter-model to the rationalization of the heart. Indeed, as it was becoming framed by medical theorizing, the heart was also "becoming more sanctified than ever before" (120). Because romanticism emphasized the importance of emotion over reason, the "Romantic heart spoke essential truths about some universal human 'nature' as well as reflecting traditional beliefs about the relationship between emotions and the divine" (122). Harriet Martineau, a famous invalid whose heart (unlike her gynaecological illness) has so far received little attention, offers a significant example of how the heart continued to be promoted as an emotional centre. Indeed, Alberti explains how Martineau rejected the gendered stereotype of the woman suffering from gynaecological disorders (she suffered from an ovarian cyst) in favour of being identified instead as a heart-disease patient. This choice brings to light the political dimension of the cardiac complaint. Alberti examines the correspondence of Martineau's physicians (Peter Mere Latham and Thomas Watson) related to her heart disease, showing how Martineau "struggled with medical authorities over the interpretation of her own cardiac symptoms" (132), refusing to relate her symptoms to her gynaecological condition (her ovarian cyst was seen as forcing her stomach into the thoracic cavity, explaining how the action of the heart and lungs could be impeded).

7 Predictably, the last chapter deals with the end of the heart as the seat of emotions. With the development of neuro-physiology emotions were more and more linked to brain mechanisms. As a consequence, the brain gradually replaced the heart as the organ linked with emotions. Thus, the study ultimately offers a journey from pathological anatomy's disenchantment with the heart to the 19th-century focus on the brain and the nervous system and the redefinition of the brain as an emotional centre. Alberti looks at the developments in anatomy and the mind sciences that changed the roles of the heart and brain and "anticipated the decline of the emotional heart" (141), and refers to the work of the most famous physiologists of the second part of the 
19th century (John Hughlings Jackson, William James, Walter Bradford Cannon, David Ferrier), scientists who specialized in cerebral localization and explained how studies in craniology and phrenology ultimately defined the brain as the seat of emotion.

8 Matters of the Heart proposes a cultural history of the heart, always making explicit the image of the heart as an emblem of emotional integrity, truth and honesty, and the renewed emphasis on the symbolical status of the heart in Victorian literary culture. Alberti's cultural approach reveals how at a time when pathological anatomy and experimental physiology undermined the Romanticization of the heart, the enduring symbolical meanings of the heart permeated the literary field, acting as a trope for female weakness. The book is a useful addition to previous studies of the heart, notably Christie Blair's literary analysis of the heart in Victorian Poetry and the Culture of the Heart (2006), calling for further research into the connections between the history of neuroscience and cardiology and their impact on culture.

INDEX

Keywords: cardiology, heart, history of medicine

Mots-clés: cardiologie, cœur, histoire de la médecine

\section{AUTHORS}

\section{LAURENCE TALAIRACH-VIELMAS}

Professeur

Université Toulouse 2 - Le Mirail

talairac@univ-tlse2.fr 